\title{
Transgenerational marking of embryonic otoliths in marine fishes using barium stable isotopes
}

\author{
Simon R. Thorrold, Geoffrey P. Jones, Serge Planes, and Jonathan A. Hare
}

\begin{abstract}
We describe a new technique for transgenerational marking of embryonic otoliths that promises significant advancements in the study of larval dispersal and population connectivity in marine fishes. The approach is based on maternal transmission of ${ }^{137} \mathrm{Ba}$ from spawning females to egg material that is ultimately incorporated into the otoliths of embryos produced by an individual after exposure to the isotope. We injected females of a benthic-spawning clownfish (Amphiprion melanopus) and a pelagic-spawning serranid (Centropristis striata) with enriched ${ }^{137} \mathrm{BaCl}_{2}$ and then reared the resulting progeny through to settlement. Barium isotope ratios in the cores of larval otoliths were quantified using laser ablation inductively coupled plasma mass spectrometry. Larval otoliths from both species contained unequivocal $\mathrm{Ba}$ isotope signatures over a wide range of doses $\left(0.8-23 \mu \mathrm{g}{ }^{137} \mathrm{Ba} \cdot \mathrm{g}\right.$ female $\left.{ }^{-1}\right)$. Female A. melanopus continued to produce marked larvae over multiple clutches and for at least 90 days after a single injection. The ability to administer different combinations of stable $\mathrm{Ba}$ isotopes provides a new means of mass-marking larvae of benthic- and pelagic-spawning fishes from multiple populations over extended spawning periods.
\end{abstract}

\begin{abstract}
Résumé : Nous décrivons une nouvelle méthode pour marquer d'une génération à l'autre les otolithes des embryons chez les poissons marins qui laisse entrevoir des progrès significatifs dans l'étude de la dispersion des larves et de la connectivité des populations. Le principe de la méthode repose sur la transmission maternelle de la femelle reproductrice à la substance des oeufs de ${ }^{137} \mathrm{Ba}$ qui est éventuellement incorporé dans les otolithes des embryons produits par les individus exposés à l'isotope. Nous avons injecté du ${ }^{137} \mathrm{BaCl}_{2}$ enrichi à des femelles de poissons-clowns (Amphiprion melanopus) à reproduction benthique et de mérous (Centropristis striata) à reproduction pélagique et nous avons ensuite élevé les rejetons produits jusqu'au moment de leur établissement. Les rapports des isotopes de baryum dans les noyaux des otolithes des larves ont été mesurés par spectrométrie de masse couplée à un plasma induit avec ablation laser. Les otolithes des larves des deux espèces contiennent des signatures isotopiques de baryum claires sur une gamme étendue de doses $\left(0,8-23 \mu \mathrm{g}{ }^{137} \mathrm{Ba} \cdot \mathrm{g}\right.$ de masse femelle $\left.{ }^{-1}\right)$. Les femelles d'A. melanopus continuent de produire des larves marquées pendant plusieurs pontes successives, durant au moins 90 jours après une seule injection. La possibilité d'administrer des combinaisons différentes d'ions stables de baryum fournit une nouvelle méthode pour faire des marquages massifs de larves de poissons à reproduction benthique ou pélagique dans plusieurs populations sur des périodes de reproduction prolongées.
\end{abstract}

[Traduit par la Rédaction]

Received 20 January 2006. Accepted 22 March 2006. Published on the NRC Research Press Web site at http://cjfas.nrc.ca on 13 April 2006.

J19119

S.R. Thorrold. ${ }^{1}$ Biology Department MS 50, Woods Hole Oceanographic Institution, Woods Hole, MA 02543, USA.

G.P. Jones. School of Marine Biology and Aquaculture and ARC Centre of Excellence for Coral Reef Studies, James Cook University, Townsville, Queensland 4811, Australia.

Serge Planes. Ecole Pratique des Hautes Etudes (EPHE), Unité Mixte de Recherche (UMR), Centre national de la recherche scientifique (CNRS) 8046, Universite de Perpignan, 66860, Perpignan cedex, France.

J.A. Hare. ${ }^{2}$ National Oceanic and Atmospheric Administration (NOAA), National Ocean Service (NOS), National Centers for Coastal Ocean Science (NCCOS), Center for Coastal Fisheries and Habitat Research, 101 Pivers Island Road, Beaufort, NC 28516, USA.

${ }^{1}$ Corresponding author (e-mail: sthorrold@whoi.edu).

${ }^{2}$ Present address: NOAA National Marine Fisheries Service (NMFS), Northeast Fisheries Science Center (NEFSC) Narragansett Laboratory, 28 Tarzwell Drive, Narragansett, RI 02882, USA. 


\section{Introduction}

Quantifying larval dispersal and connectivity remains a major challenge when applying spatially explicit models to the management of marine fish populations (Sale et al. 2005). Coupled biophysical models are providing insights into potential connectivity among reef fish populations (Cowen et al. 2006), but there are remarkably few direct estimates of larval dispersal. Our current lack of knowledge is primarily due to the difficulty of conducting mark-recapture studies for species characterized by the production of large numbers of small pelagic offspring that are quickly diluted in large volumes of water while suffering high mortality rates. Thorrold et al. (2002) recently reviewed a range of chemical markers that have been used to mark marine fish larvae. They noted that only fluorescent compounds have been successfully applied in situ to label fish embryos (Jones et al. 1999, 2005).

We describe a new technique for mass marking fish larvae that relies on transgenerational transfer of a $\mathrm{Ba}$ isotope spike from gravid females to the embryonic otoliths of their offspring. To test the effectiveness of the new approach, we addressed the following specific questions. Can Ba isotope labels be detected in otoliths from larvae of both demersaland pelagic-spawning fishes? Are departures from natural isotope ratios in larval otoliths correlated with maternal dose rates? Will females continue to transfer $\mathrm{Ba}$ isotopes to the offspring of subsequent clutches after the initial exposure? And finally, is the mark restricted to the core of the otolith, providing unequivocal evidence that the chemical mark is maternally transmitted? If successful, isotope labeling via maternal transmission will provide fish ecologists with a powerful new method for empirical tests of larval dispersal in aquatic environments.

\section{Materials and methods}

We examined transgenerational marking of embryonic otoliths in the fire clownfish (Amphiprion melanopus), a benthic-spawning coral reef fish that broods eggs for 810 days before hatching, and in black seabass (Centropristis striata), a pelagic-spawning temperate reef fish. Adult spawning pairs of A. melanopus were maintained in $100 \mathrm{~L}$ plastic tanks at James Cook University's Marine Aquarium Facility (Townsville, Queensland, Australia). The feeding regime consisted of ad libitum feeding once daily with tropical marine flakes and an occasional feeding of frozen squid and pilchards. Water temperature and salinity in the tanks ranged between 22.8 and $31.0{ }^{\circ} \mathrm{C}$ and between $32 \%$ and $36 \%$, respectively. Terracotta pot plant holders were provided as a suitable artificial surface for egg laying.

A solution of $0.55 \mathrm{mg} \mathrm{BaCl} \mathrm{mater}^{-1}$, containing $81.9 \%$ ${ }^{137} \mathrm{Ba}$ and $17.4 \%{ }^{138} \mathrm{Ba}$ obtained from Oak Ridge National Laboratory (Oak Ridge, Tennessee), was injected into the abdominal cavity of female A. melanopus. We injected females with ${ }^{137} \mathrm{Ba}$ at dose rates of $0.45(n=3), 2.3(n=2)$, $4.5(n=2)$, and $23(n=2) \mu \mathrm{g}{ }^{137} \mathrm{Ba} \cdot \mathrm{g}$ female ${ }^{-1}$, along with two controls in which females were injected with the same volume of a $0.9 \% \mathrm{NaCl}$ solution as that administered to the highest ${ }^{137} \mathrm{Ba}$ dose treatment. Females were first anaesthetized in a bucket containing $10 \mathrm{~mL}$ of clove oil mixed with
$50 \mathrm{~mL}$ ethanol and diluted with $500 \mathrm{~mL}$ seawater and then electronically weighed to determine the injection volume of $\mathrm{BaCl}_{2}$ for each fish. The Ba solution was administered using a hypodermic needle, and each fish was then revived in aerated salt water and returned to its initial tank. Females were maintained for up to 87 days after injection, and all clutches spawned following the injections were reared to settlement. Unfortunately spawning behaviour of females after the injection was inconsistent, leading to a lack of replication for the 4.5 and $23 \mu \mathrm{g} \cdot \mathrm{g}$ female $^{-1}$ treatments.

At the end of an 8-10 day gestation period, pre-hatch egg clutches were removed from the brooding adults at dusk and taken to an indoor, controlled environment hatchery. Larvae were reared in the same hatching tank until settlement at approximately 14 days using standard greenwater methods (reviewed by Wilkerson 1998). Sampling of larvae occurred approximately 14 days after hatching, when all surviving larvae were removed from the rearing tubs. The saggital otolith pairs were extracted from the larvae and stored dry in $1.5 \mathrm{~mL}$ plastic centrifuge vials.

Adult C. striata were collected in the Newport River estuary and held at the National Marine Fisheries Service's laboratory in Beaufort, North Carolina. Three females and two males were conditioned for 1 year on artificial diet and then allocated to a separate tank where the temperature was maintained with a flow-through, filtered seawater system at approximately $20^{\circ} \mathrm{C}$ and $32 \%$ o salinity. Females were injected with human chorionic gonadotropin to induce spawning. The fish were also injected subcutaneously with a $0.55 \mathrm{mg} \mathrm{BaCl} \cdot \mathrm{g}$ water $^{-1}$ solution at a dosage rate of $0.8 \mu \mathrm{g}{ }^{137} \mathrm{Ba} \cdot \mathrm{g}$ female ${ }^{-1}$ at the same time. Eggs were collected 8 days later, and viable eggs were distributed to two tanks and incubated at a density of $100 \mathrm{eggs} \cdot \mathrm{L}^{-1}$. Larvae from one of the tanks experienced high mortality, and therefore all individuals used subsequently came from a single tank. We also obtained $C$. striata larvae from Great Bay Aquaculture in Portsmouth, New Hampshire, that were spawned and reared for approximately 60 days using standard procedures at the facility. Otoliths from these larvae were used as analytical controls for the $\mathrm{Ba}$ isotope analyses.

In preparation for laser ablation inductively coupled plasma mass spectrometry (ICP-MS) analysis, larval otoliths from $A$. melanopus and $C$. striata were scraped clean with acidwashed glass probes, ultrasonically cleaned in ultrapure water for 5-7 min, rinsed with ultrapure $\mathrm{H}_{2} \mathrm{O}_{2}$, and then rinsed three times with ultrapure water. After drying, otoliths were mounted singly on clean petrographic slides with cyanoacrylic glue. One randomly chosen otolith was ground to the midplane on $3 \mu \mathrm{m}$ lapping film and then sonicated for $5 \mathrm{~min}$ to remove surface contamination. After triple rinsing with ultrapure water, otoliths were left to dry in a class 100 laminar flow hood for $24 \mathrm{~h}$. Once dry, otoliths were remounted on petrographic slides using double-sided tape for Ba isotopic analyses

We analysed $\mathrm{Ba}$ isotope ratios in otolith cores using a New Wave Research UP213 laser ablation system coupled to a Thermo Finnigan Element2 ICP-MS located at the Woods Hole Oceanographic Institution (Woods Hole, Massachusetts). Instrument setup incorporated the use of a wet aerosol for both laser and solution analyses as outlined by Thorrold et al. (2001). We measured ${ }^{137} \mathrm{Ba}$ and ${ }^{138} \mathrm{Ba}$ in otolith samples, 
Fig 1. (a) Mean ( \pm standard deviation, SD) ${ }^{138} \mathrm{Ba} /{ }^{137} \mathrm{Ba}$ ratios in larval otolith cores from individual clutches of Amphiprion melanopus (open squares) and from otoliths in Centropristis striata larvae (solid squares), spawned by females injected with enriched ${ }^{137} \mathrm{BaCl}_{2}$ at several dosage rates and control otoliths $( \pm 3$ $\mathrm{SD}$; dashed line indicates the natural ${ }^{138} \mathrm{Ba} /{ }^{137} \mathrm{Ba}$ ratio). (b) Mean $( \pm \mathrm{SD}){ }^{138} \mathrm{Ba} /{ }^{137} \mathrm{Ba}$ ratios in larval otolith cores from clutches produced by of $A$. melanopus females initially injected with ${ }^{137} \mathrm{BaCl}_{2}$ at dosage rates of $0.45 \mu \mathrm{g}{ }^{137} \mathrm{Ba} \cdot \mathrm{g}$ female ${ }^{-1}$ (open squares), $2.3 \mu \mathrm{g}{ }^{137} \mathrm{Ba} \cdot \mathrm{g}$ female ${ }^{-1}$ (solid diamonds), $4.5 \mu \mathrm{g}{ }^{137} \mathrm{Ba} \cdot \mathrm{g}$ female $^{-1}$ (open circles), and $23 \mu \mathrm{g}{ }^{137} \mathrm{Ba} \cdot \mathrm{g}$ female ${ }^{-1}$ (solid triangles) and then left to spawn at natural intervals. The shaded box represents mean $( \pm 3 \mathrm{SD}){ }^{138} \mathrm{Ba} /{ }^{137} \mathrm{Ba}$ ratios in control otoliths $(n=20)$. (c) Laser ablation inductively coupled plasma mass spectrometry was used to analyze $\mathrm{Ba}$ isotope ratios from a $50 \mu \mathrm{m} \times$ $50 \mu \mathrm{m}$ raster centered on the nucleus of otoliths from

A. melanopus (shown in the photomicrograph) and C. striata.

a dissolved otolith reference material (Yoshinaga et al. 2000), and a $2 \% \mathrm{HNO}_{3}$ instrument blank. Ba isotope ratios, expressed as ${ }^{138} \mathrm{Ba} /{ }^{137} \mathrm{Ba}$, were then calculated from blankcorrected abundances following correction for instrument mass bias. The mass bias correction was calculated from the otolith reference material, dissolved in $2 \% \mathrm{HNO}_{3}$, and diluted to a final $\mathrm{Ca}$ concentration of $40 \mu \mathrm{g} \cdot \mathrm{g}^{-1}$, that was run after every three otoliths. We assumed that the otolith reference material contained the natural isotope ratio for ${ }^{138} \mathrm{Ba} /{ }^{137} \mathrm{Ba}$ of 6.385 . Isotopic analysis of a single otolith using our method takes approximately $2 \mathrm{~min}$, and over 100 otoliths can be processed in a single day.

\section{Results and discussion}

Barium isotope ratios in otolith nuclei of larvae $(n=5)$ from the first egg clutch spawned by A. melanopus females between 3 and 21 days after injection with enriched ${ }^{137} \mathrm{Ba}$ differed considerably from ${ }^{138} \mathrm{Ba} /{ }^{137} \mathrm{Ba}$ ratios in otoliths of control larvae (Fig. 1a). ${ }^{138} \mathrm{Ba} /{ }^{137} \mathrm{Ba}$ ratios in otoliths $(n=$ 20) from control larvae (mean \pm standard deviation, $6.37 \pm$ 0.07) were, in turn, indistinguishable from natural ${ }^{138} \mathrm{Ba} /{ }^{137} \mathrm{Ba}$ ratios of 6.385 . Enriched ${ }^{137} \mathrm{Ba}$ was clearly transmitted from females to their offspring, presumably via incorporation of $\mathrm{Ba}$ from maternal yolk. We also found considerable variability among clutches within treatments, suggesting that either there were individual differences in the movement of $\mathrm{Ba}$ ions among different tissues of the spawning females or that dosages were unevenly administered. Nonetheless, ${ }^{138} \mathrm{Ba} /{ }^{137} \mathrm{Ba}$ ratios $(2.6 \pm 1.3)$ at the lowest dosage rate of $0.45 \mu \mathrm{g}{ }^{137} \mathrm{Ba} \cdot \mathrm{g}$ female ${ }^{-1}$ were still clearly distinct from the natural ratios (Fig. 1a).

Turnover rates of $\mathrm{Ba}$ in $A$. melanopus tissues will presumably determine the usefulness of $\mathrm{Ba}$ isotope labeling in field applications where it is necessary to release labeled larvae over a period of weeks to months. We therefore reared clutches that were spawned up to 87 days after initial ${ }^{137} \mathrm{Ba}$ injections to estimate the length of time over which females continue to produce marked individuals. Spawning durations after injections differed among females; nonetheless, Ba isotope ratios in larval otoliths remained clearly distinguishable from controls for at least 3 months after initial injections
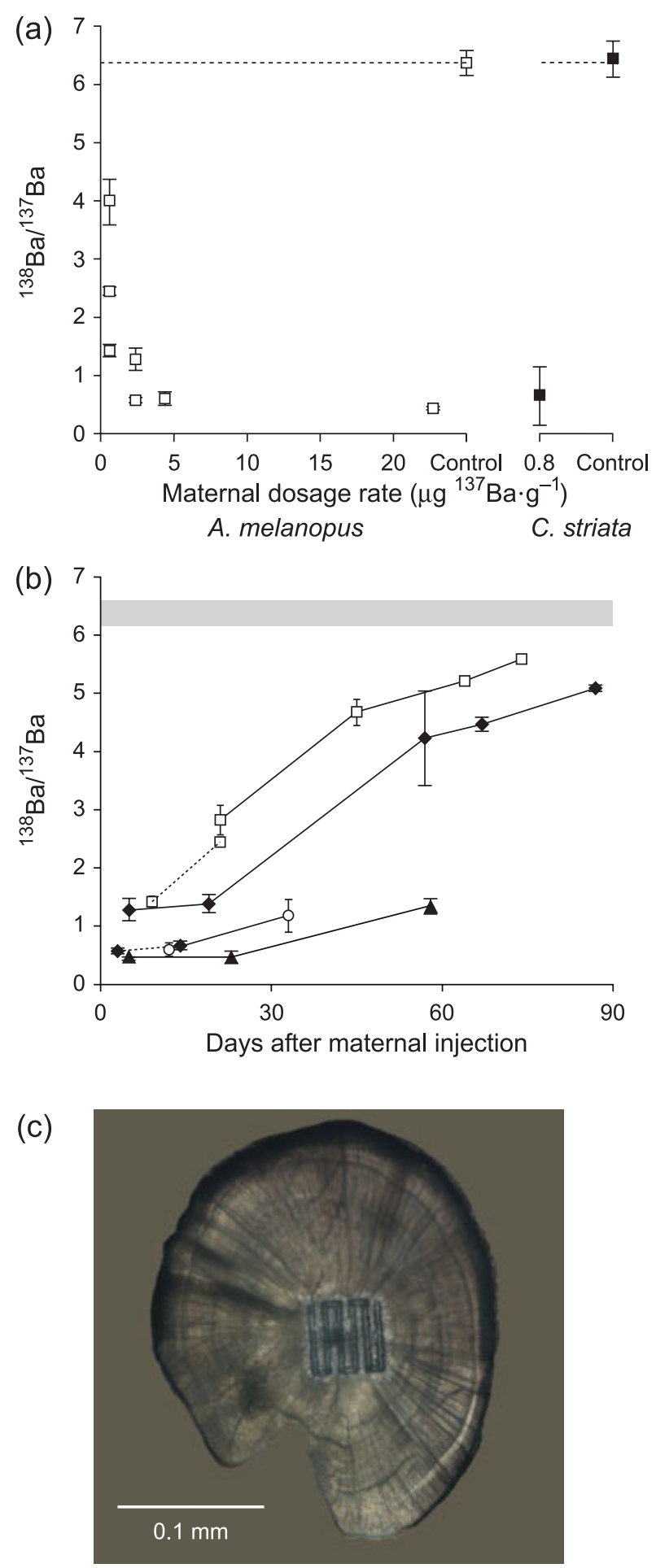

(Fig. 1b). Females injected with lower amounts of ${ }^{137} \mathrm{Ba}$ approached isotopic equilibrium with the environment more quickly than those females given higher doses, even though initial ${ }^{138} \mathrm{Ba} /{ }^{137} \mathrm{Ba}$ ratios in larval otoliths were quite similar.

Maternal transmission of enriched isotopes to embryonic otoliths is more likely to occur in benthic-spawning fishes than in species that produce pelagic eggs with smaller amounts of yolk. We found, however, that ${ }^{137} \mathrm{Ba}$ was successfully transmitted from spawning females to embryonic otoliths of a pelagic-spawning serranid, C. striata (Fig. 1a). 
${ }^{138} \mathrm{Ba} /{ }^{137} \mathrm{Ba}$ ratios $(n=20)$ in otoliths from larvae $(0.6 \pm 0.5)$ reared from females injected with enriched ${ }^{137} \mathrm{Ba}$ at a dosage rate of $0.8 \mu \mathrm{g}{ }^{137} \mathrm{Ba} \cdot \mathrm{g}$ female $^{-1}$ were substantially different from control larvae $(6.4 \pm 0.1, n=10)$. Barium isotopes in the control larvae were again indistinguishable from natural ${ }^{138} \mathrm{Ba} /{ }^{137} \mathrm{Ba}$ ratios (Fig. 1a). The ${ }^{138} \mathrm{Ba} /{ }^{137} \mathrm{Ba}$ ratios were, therefore, lower in otoliths of $C$. striata larvae than in otoliths from larvae spawned by A. melanopus females given a similar ${ }^{137} \mathrm{Ba}$ dose. However, we cannot say if the difference in effectiveness of the ${ }^{137} \mathrm{Ba}$ injections was due to interspecific variability in Ba metabolism or because injections were administered in different body tissues. Finally, we examined $\mathrm{Ba}$ isotope profiles across several otoliths from control and treatment groups to determine if the enriched ${ }^{137} \mathrm{Ba}$ signature was restricted to the pre-hatch region of otoliths. Isotope ratio profiles showed that the isotopic label was confined to an area no more than $\sim 50 \mu \mathrm{m}$ from the center of treatment otoliths (Fig. 2). The profiles were, however, not symmetrical, presumably because of the time required to wash out the enriched ${ }^{137} \mathrm{Ba}$ signal from the sample introduction system of the ICP-MS. As expected, the control otolith showed little variation in ${ }^{138} \mathrm{Ba} /{ }^{137} \mathrm{Ba}$ ratios at any point along the profile.

$\mathrm{Ba}$ is found naturally in otoliths at concentrations typically ranging from 1 to $10 \mu \mathrm{g} \cdot \mathrm{g}^{-1}$ (Campana and Thorrold 2001). The element is, however, toxic and likely to be poisonous to fishes at high concentrations. Although there are no data available for fishes, researchers have noted increased mortality of juvenile and adult rats to a single acute exposure of $\mathrm{BaCl}_{2}$ at doses of $100-200 \mu \mathrm{g} \mathrm{Ba} \cdot \mathrm{g}$ body mass ${ }^{-1}$ (Borzelleca at al. 1988). None of the adult females in the treatment or control groups died during our experiment, and most of the females continued to spawn after we administered the injections, indicating that the dosages $(0.2-23 \mu \mathrm{g}$ ${ }^{137} \mathrm{Ba} \cdot \mathrm{g}$ female ${ }^{-1}$ ) were below lethal levels for $A$. melanopus. To examine if $\mathrm{Ba}$ exposure had an effect on larval development, we tracked embryo development times and measured the diameter of larval otoliths to quantify otolith precipitation rates. Embryos from treatment females took the same amount of time to hatch (mean $\pm \mathrm{SD}=8 \pm 0.9$ days) as those from control groups (mean $=8$ days). Mean precipitation rates of larval otoliths in treatment groups $(17.2 \pm 1.3$ $\mu \mathrm{m} \cdot \mathrm{day}^{-1}$ ) were also similar to those from control groups $\left(18.6 \pm 1.2 \mu \mathrm{g} \cdot \mathrm{day}^{-1}\right)$. Otolith precipitation rates are typically correlated with somatic growth (Campana and Thorrold 2001), suggesting that growth rates were similarly unaffected by maternal effects of Ba exposure.

The use of enriched isotopes to label embryonic otoliths via maternal transmission is a promising new in situ method of marking larvae from benthic- and pelagic-spawning fish species. Once captured and injected with an isotope, a single female will potentially produce millions of marked larvae during a spawning season. The isotopic label then remains indelibly locked in the core of otoliths for the life of the tagged individual. The commercial availability of four stable isotopes of $\mathrm{Ba}\left({ }^{135} \mathrm{Ba},{ }^{136} \mathrm{Ba},{ }^{137} \mathrm{Ba}\right.$, and $\left.{ }^{138} \mathrm{Ba}\right)$, used individually or in combination, allows for 13 unique tags that can be applied to different individuals or subpopulations. Alternative methods for chemical marking of marine fishes and invertebrates require exposure of the embryos or early stage larvae to fluorescent compounds that are incorporated into
Fig. 2. (a) ${ }^{138} \mathrm{Ba} /{ }^{137} \mathrm{Ba}$ profiles across a control otolith from a Centropristis striata larva (dashed line indicates the natural ${ }^{138} \mathrm{Ba} /{ }^{137} \mathrm{Ba}$ ratio) and $(b)$ otoliths from two larvae (open and solid squares) spawned by treatment females injected with enriched ${ }^{137} \mathrm{BaCl}_{2}$. Arrow shows direction of laser movement along the profile. (c) Laser ablation inductively coupled plasma mass spectrometry was used to analyze $\mathrm{Ba}$ isotope ratios from profiles (a line is shown in the photomicrograph of a sectioned otolith from a $C$. striata larva) through the otolith nucleus.
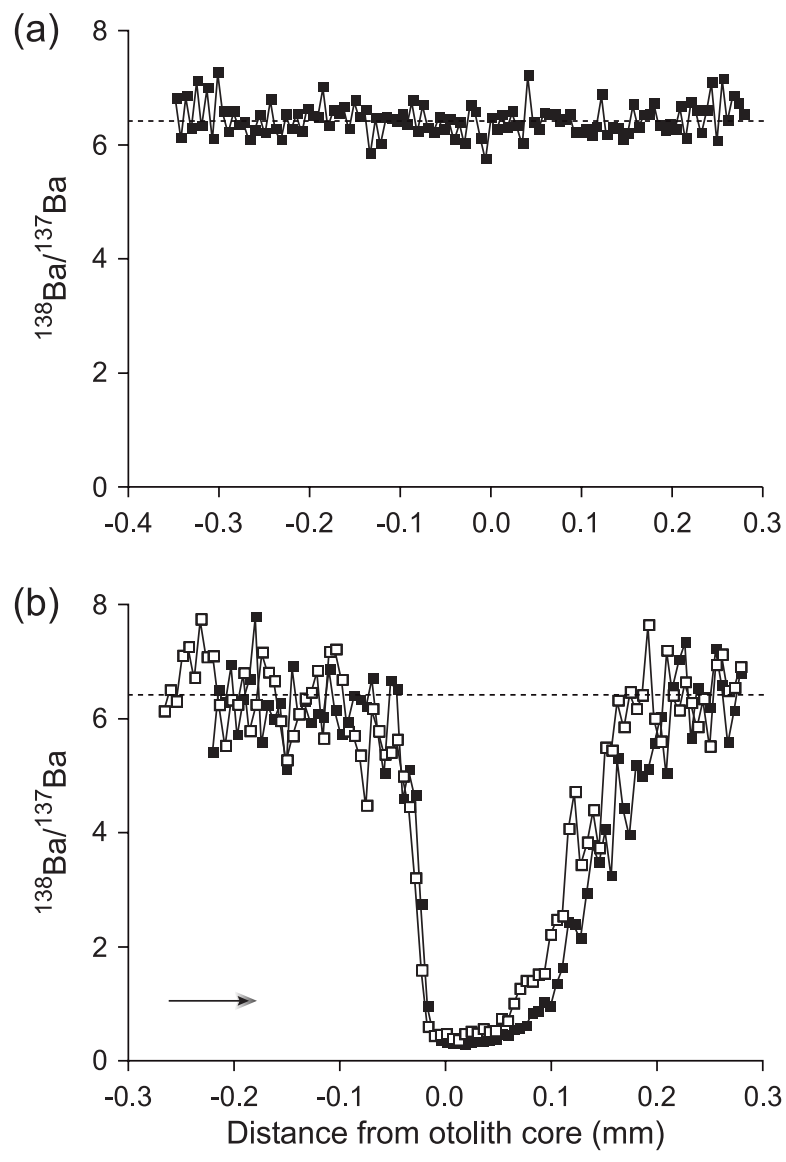

(c)

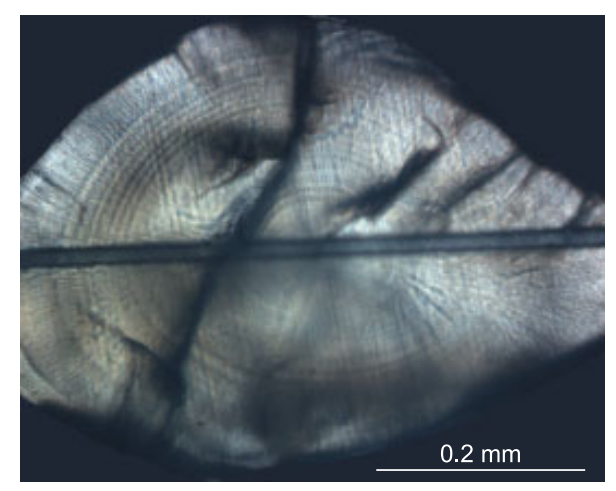

calcified tissues (Levin et al. 1993; Thorrold et al. 2002). This, in turn, means that the eggs have to be easily handled in the field, as in the case of some damselfishes (Jones et al. 1999, 2005), or alternatively that the species of interest is in culture and larvae can be marked in the lab before release (Moran and Marko 2005). Transgenerational marking of embryos using enriched isotopes provides a new mechanism for 
generating large numbers of known origin larvae that are released in situ and under natural conditions by spawning females. Information from these releases will, in turn, generate empirical estimates of larval dispersal that can be used to test the ability of coupled biophysical models to accurately capture connectivity patterns in fish populations.

\section{Acknowledgements}

Funding for this study was provided by the National Science Foundation through grants OCE-0215905 and OCE0424688, Discovery Grant DP 0208120 from the Australian Research Council, and the Oak Foundation. We thank Amy Forrest, Brian Degan, Andrew Kaus, Bridgid Green, James Morris, and Peter Wruck for assistance with larval rearing; Gretchen Martin and Jennifer FitzGerald for help with preparation and analysis of otoliths; and Travis Elsdon, Benjamin Walther, and two anonymous reviewers for helpful comments on the manuscript.

\section{References}

Borzelleca, J.F., Condie, L.W., Jr, and Egle, J.L., Jr. 1988. Shortterm toxicity (one- and ten-day gavage) of barium chloride in male and female rats. J. Am. Coll. Toxicol. 7: 675-685.

Campana, S.E., and Thorrold, S.R. 2001. Otoliths, increments, and elements: keys to a comprehensive understanding of fish populations? Can. J. Fish. Aquat. Sci. 58: 30-38.
Cowen, R.K., Paris, C.B., and Srinivasan, A. 2006. Scaling of connectivity in marine populations. Science (Washington, D.C.), 311: $522-527$.

Jones, G.P., Milicich, M.J., Emslie, M.J., and Lunow, C. 1999. Self-recruitment in a coral reef fish population. Nature (London), 402: 802-804.

Jones, G.P., Planes, S., and Thorrold, S.R. 2005. Coral reef fish larvae settle close to home. Curr. Biol. 15: 1314-1318.

Levin, L.A., Huggett, D., Myers, P., and Bridges, T. 1993. Rareearth tagging methods for the study of larval dispersal by marine invertebrates. Limnol. Oceanogr. 38: 346-360.

Moran, A.L., and Marko, P.B. 2005. A simple technique for physical marking of larvae or marine bivalves. J. Shellfish Res. 24: 567-571.

Sale, P.F., Cowen, R.K., Danilowicz, B.S., Jones, G.P., Kritzer, J.P., Lindeman, K.C., Planes, S., Polunin, N.V.C., Russ, G.R., Sadovy, Y.J., and Steneck, R.S. 2005. Critical science gaps impede use of no-take fishery reserves. Trends Ecol. Evol. 20: 74-80.

Thorrold, S.R., Latkoczy, C., Swart, P.K., and Jones, C.M. 2001. Natal homing in a marine fish metapopulation. Science (Washington, D.C.), 291: 297-299.

Thorrold, S.R., Jones, G.P., Hellberg, M.E., Burton, R.S., Swearer, S.E., Neigel, J.E., Morgan, S.G., and Warner, R.R. 2002. Quantifying larval retention and connectivity in marine populations with artificial and natural markers. Bull. Mar. Sci. 70: 291-308.

Wilkerson, J.D. 1998. Clownfishes: a guide to their captive care, breeding and natural history. Microcosm Ltd., Charlotte, Vt.

Yoshinaga, J., Nakama, A., Morita, M., and Edmonds, J.S. 2000. Fish otolith reference material for quality assurance of chemical analyses. Mar. Chem. 69: 91-97. 